\title{
Søgninger og fordybelser - litteraturoversigt
}

Af Jørn Hansen og Niels Kay ser Nielsen

I lighed med de foregående år vil vi også $\mathrm{i}$ dette års udgave af Idrætshistorisk Årbog omtale og kommentere en række af de idrætshistoriske og kropskulturelle værker og artikler, der har set dagens lys inden for det sidste års tid, idet det er vores opfattel$\mathrm{se}$, at denne historiografiske oversigt har en vis relevans $i$ såvel forsknings- og undervisningsssammenhænge som hos de læsere, der er interesserede $\mathrm{i}$ idrættens og kroppens historie $i$ almenhed.

Vi kan med glæde konstarere, at strømmen af publikationer på dette område fortsætter år for år. Medens man i 1980erne ikke kunne være helt sikker på, at interessen for idrettens og kroppens historie var andet end et kortvarigt modefænomen, der ville dø ud igen som så mange andre 1980er-initiativer fra neden, er denne tvivl i dag vejret bort. Ganske vist er vores genstandsområde ikke stort, og ganske vist er de forsknings- og undervisningsmæssige bevillinger ikke så omfattende, som man kunne ønske sig, men både læsernes interesse og forskernes arbejde vidner om, at idrætten og kropskulturen i dag akcepteres som en naturlig del af det samlede kulturhistoriske felt. Både forskningen og læserinteressen er modnet og tilsyneladende kommet for at blive. At kroppen $\mathbf{i}$ dag står centralt placeret $\mathrm{i}$ såvel den videnskabelige diskurs, inden for områder som (kultursociologi, historie, humangeografi, antropologi, symbolsk interaktionsterori, kunsthistorie og videnskabsteori, som på det per- sonlige, livsfilosofiske plan blokerer selvsagt ikke herfor.

På den anden side må man også gøre opmærksom på, at selv om genstandsområdet: forskning i idrettens historie og kroppens kultur i dag er kommet i en god gænge, sker der konstant ombrydninger og nyvurderinger. Firkantet sagt kan man ane konturerne af en udvikling, hvor idretsforskere der tidligere så med yderst kritiske øjne på sporten og dens udøvere i dag indtager en positiv holdning til sport og sportsfolk, medens folk der tidligere så på sport og idræt med fascinerede øjne, som også havde blik for sportens utopiske og frigørende elementer, i dag indtager en noget mere forbeholden position. Man har på baggrund heraf årsag til at håbe på dels en større tilbøjelighed til dialog, dels en mere nuanceret $\mathrm{og}$ differentieret stillingtagen til idrætten, og måske også til sporten. I hvert fald er det glædeligt, at man i dag fra forskerside er fri for, som retorisk besværgelse, at skulle ønske idretten og sporten hen, hvor peberet gror.

Man kan så håbe på, at de store idrætsorganisationer også har selvkritisk blik for henholdsvis eliteidrættens kritisable sider og tilløbene til hulhed i den megen snak om »folkelighed « $i$ idrætsarbejdet, som vist ingen har patent på. I det mindste spores der tendenser til nytænkning i DIF medlemsblad Idrætsliv, som i årets løb har fået nyt tabloidformat, ligesom DDGU's velredigerede Ungdom og Idræt $\mathrm{i}$ stigende grad 
åbner op for problematisering af de nok så velkendte slagord. Begge disse blade er sammen med DDSG\&I's Dansk Idræt gamle travere, men de fortjener alligevel at blive nævnt $\mathrm{i}$ denne oversigt, ligesom băde Focus og Tidsskrift for Idræt lever og har det godt.

Tendensen til fornyelse og omprøvning på baggrund af et efterhånden fast etableret fundament er nu én side af den udviklingstendens, der lader sig efterspore. En anden tendens vedrører tilbøjeligheden til en venden tilbage til den rent idrætslige og færdighedsmæssige del af kropskulturen. Ovenpå 1980ernes dyrkelse af ikke bestemte discipliner, men kropsaktiviteter $\mathrm{i}$ al almindelighed i lutter diffusitet og uspecificitet fornemmer man, $\mathrm{i}$ takt med trenden $\mathrm{i}$ øvigt $i$ samundet, en tendens $i$ retning af indkredsning af de specifikke egenskaber og kvaliteter i idrætten. Mere og mere spørges der efter idrættens særart og dens konstituerende principper. Det indebærer en opsøgning af ikke mindst idrættens fænomenologiske egenskaber, ligesom det på det rent kropslige plan medfører en fordybelse $\mathrm{i}$ idrættens taktile og kinæstetiske egenskaber.

Denne interesse for idrættens særart er endnu ikke slået igennem i større arbejder og længere artikler (nye ideer ventileres ofte $\mathrm{i}$ kortform), men man aner anslaget $\mathrm{i}$ et af de mere interessante bidrag til idrætsdebatten $\mathrm{i}$ ărets $l ø b$, nemlig Eigil Jespersens pamflet Mesterlare $i$ idrat. Andet brev til DDGU'erne. Her slås det fast, at sportens styrke er, at den for alt andet tager udgangspunkt i kroppen og dens bevægelser, og at dette samtidig indebærer et fundament for erkendelse. Vores viden er nemlig først og fremmest kropslig, betones det. I kraft af en sădan opfattelse ser man dels en overskridelse af det ideologikritiske skoleridt, som har været så dominerende i kulturanalysen generelt og sportskritikken specifikt, dels et opgør med den lige så kropsangste tanke om, at idræt og kropsaktiviteter er ekspressive $i$ sit væsen. Eigil Jespersen argumenterer overbevisende for, at sport og idræt ikke udtrykker noget, men i sig selv rummer viden.

Denne forestilling om den tavse viden spiller også en afgørende rolle i Tor Nørretranders' nok så omtalte mediehit Mork verden, som blandt meget andet også er en dygtig sammenskrivning af de tanker, som har været på vej til sig selv gennem de senere ăr vedrørende vores kropslige væren, nemlig at vi før alt det andet først er sansemennesker. Her ser man blandt mange andre relationer også forbindelsen til filosoffer som Maurice Merleau-Ponty, Gaston Bachelard og K.E. Løgstrup.

Denne forbindelse til fænomenologien påpeges da også i flere af artiklerne i Willy Thrysøe og Ole Fogh Kirkeby (red.). Krop, intuition og bevidsthed, som er en antologi med reaktioner på Nørretranders' bog, der bl.a. kritiserer den manglende inddragelse af sprogliggørelsens bidrag til erkendelse og sprogets indvirkning på kroppen og dens viden. Nørretranders' tendens til henholdsvsis kropslig metafysik og længsel efter autenticitet er en anstødssten for flere af indlæggene i denne interessante debatbog, der fortjener den samme udbredelse som sit forlæg.

I en anden dygtig sammenskrivning befinder genstanden for undersøgelsen sig ligledes mellem humaniora og naturvidenskab. Med ønsket om at formulere et nyt fag, der kan erstatte den ufrugtbare tilstand mellem psykologi og medicin, har Peters Elsass i Sundhedspsykologi. Et nyt fag mellem humaniora og naturvidenskab (1992) beskrevet en række modsætninger: sundhed og sygdom, psyke og soma, krise og udvikling, diagnose og behandling, forebyggelse 
og formynderi. Bogen kan săledes ogsă medvirke til en afklaring af forholdet mellem naturvidenskab og humaniora.

Overfor denne interesse for en basal kropslighed står den tendens til konstruktion af kropslighed, der kommer til udtryk i den (post)moderne show-sport, og i særdeleshed i den medieskabte udgave heraf. Man har længe savnet undersøgelser af denne tv-udformede show-sport, ligesom man har savnet komparative analyser af DR-TV's og TV 2' sportsudsendelser. Tidsskriftfor Idrat 1992 nr. 3, der som tema havde »idræt i medierne«, indeholder en første, kort artikel herom af Niels Kayser Nielsen. Desuden arbejder Kirsten Frandsen, som er kandidatstipendiat ved Danmarks Journalisthøjskole i Aarhus, med dette tema, og der kan være grund til at følge hendes publiceringer herom fremover med interesse. Indtil videre har hun bl.a. skrevet herom i Idratsliv 1991, nr. 11 med titlen »Den elektroniske søndagssport $\ll$.

Vedrørende større værker udkommet inden for det sidste ărs tid kan nævnes, at Jørn Møller nu har fuldendt sin serie om gamle danske leg og spil og deres kulturhistorie. De to sidste bind i serien hedder henholdsvis Føde en Bjørn og 99 andre gamle smidighedsøvelser og styrkelege og Snore Vibe og 99 andre gamle kamp-og kaplege. Med dette samleværk, som er udfomet med grundighed og forskningmæssige udblik, har dansk idrætshistorie nu både en enestående dokumentation og et solidt grundlag for videre studier på området. Beskrivelsen og typologiseringen af legene er interessant $i$ sig selv, ligesom bøgerne rummer masser af kulturhistoriske perspektiveringer. Dette værk står stærkt - også i sammenligning med udlandet.

I Det kongelige Biblioteks lille oversete tidsskrift Magasin findes en interessant ar- tikel, nemlig John T. Lauridsens Fan Nordsøbad - mellem dansk og tysk 18901904. Artiklen beskæftiger sig, velskrevet og humorfyldt, bl.a. med den aktuelle problemstilling vedrørende forholdet mellem kropskultur og nationalisme og udgør dernæst en god inspirationskilde for den kobling mellem kulturhistorie og fænomenologi, der åbner sig $i$ takt med interessen for kroppens ontologi og dens relation til de fire grundelementer, hvoraf vandet ikke er det mindst intressante. Der er grund til at tro, at der $\mathrm{i}$ de kommende ăr vil vise sig en yderligere interesse herfor.

Bjarne Ibsen, Per Jørgensen, Reinhard Stelter, Else Trangbæk: Idrat $i$ bevagelse. Humanistisk og samfundsvidenskabelig idratsteori anlægger både et idrætshistorisk og et sociologisk perspektiv på idrætten. Bogen er ikke mindst skrevet for at dække behovet for en introduktion til emnet i gymnasiets idrætsundervisning. Den indeholder ud over den tematiske behandling en række gode opgaveforslag, en litteraturliste i uddrag samt en tidstavle over idrætten og kropskulturens udvikling i Danmark siden 1800.

Blandt artiklerne i Niels Kayser Nielsen, Michael Andersen og Jørn Hansen (red.): Kroppens spejl - en antologi om idrat og sundhed er der flere, som behandler idrætshistoriske emner, medens andre beskæftiger sig med kropskultur i bredere forstand. Hovedvægten i antologien er lagt på en belysning af relationen mellem fysisk aktivitet og sundhedsfremme. Den indeholder et par artikler - bl. a. om madkultur og ældreliv - som lægger afstand til alt for firkantede og »frelste« opfattelser af, hvad der er sundt, ligesom det som noget nyt inden for idrætshistorien påvises, at sundhedsaspektet spillede en betragtelig rolle $\mathrm{i}$ etableringen af den nye legemskultur i Det moderne Gennembrud. 
Dobbeltnummeret Kønnet $i$ historien, Den Jyske Historiker nr. $58-59$ (1992) sætter $k \emptyset n$ og sociale relationer - og dermed kroppen - i centrum. Hans Bonde bidrager med sine efterhånden velkendte overvejelser om Konnet $i$ kroppen - om historisk køns- og kropssemiotik. Vigtig er især Birgitte Possings artikel Køn og kvindelighed - hvilke historiske kategorier? med en præcisering af kønnet (kroppen!) som henholdsvis en normativ, en sociologiskdemografisk og en subjektiv kategori. Overvejelser, der er udsprunget af hendes arbejde med afhandlingen om Natlie Zahle. Dertil kommer yderligere to spændende bidrag om køns- og kropskultur: Wilhelm von Rosens Den paderastiske subkulturs opståen $i$ København $i$ 1860'erne og den amerikanske historiker John Gillis' Bringing up Father. Artikler, der begge tilskriver maskuliniteten en anden betydning end de sidste 20 års kønsforskning.

Niels Kayser Nielsen: Fra Robin Hood tilfodbold. En kulturanalytisk studie af arbejderklassens kropskultur $i$ England $i$ 1800-tallet (en lettere omarbejdet udgave af sammes ph.d.-afhandling) handler om »opdagelsen « af kroppen i den engelske arbejderklasse i 1800 -tallet, som den kom til udtryk i arbejde, politik, fest, og idræt. Kropskulturen ses i lyset af det omgivende samfunds økonomiske, sociale, politiske og kulturelle forhold, hvor kroppen - især i opbrudstider - bruges som led i en fortolkning af forholdet mellem individ og kollektiv. Bogen indeholder desuden forskningsmæssige oversigter over dansk og udenlandsk litteratur om idrætshistorie, kropskultur, mentalitetshistorie og historieteori, og der præsenteres en række centrale kulturanalytiske begreber $\mathrm{i}$ behandlingen af bl.a. politiske møder, hanekampe, »blå mandage « og fodboldkampe.

Til rækken af ph.d.-afhandlinger føjer sig i 1992 Bjarne Ibsens Frivilligt arbejde $i$ idratsforeninger. Et vægtigt sociologisk bidrag til den stadig fortsatte diskussion om foreningernes aktualitet, som afhandlingen i høj grad, hvad angår idrætsforeningerne, er fortaler for. Interessant er derfor overvejelserne over forholdet mellem forskellige foreningstypers gennemslagskraft ikke blot på det medlemsmæssige område, men også på det aktiverende og medarbejdende område. Også en analyse, der understøtter idrætsforeningernes fortsatte aktualitet.

Travsportens historie er interessant, ikke mindst fordi også dette felt åbner for muligheden af at koble mellem kulturhistorie og idræt. Gá med $i$ Lunden - dansk travsports historie (1991) af Flemming Ettrup er den første samlede fremstilling af travsportens og -avlens historie i Danmark. Bogen er netop ikke blot travhistorie i snæver forstand, men også et stykke spændende kulturhistorie, der brydes i travets lys og behandles med stor hengivenhed af forfatteren.

Samme hengivenhed gør sig forventeligt gældende i velkendte Helle Gotveds erindringsbog Barn $i$ Gymnastikhuset (1992). Det er altid fornøjeligt at modtage fra en, der har noget på sinde.

I oktober 1991 arrangerede det internationale forskernetværk IIAC et seminar, på Nyborg Vandrerhjem. Denne sammenslutning, hvori også flere danske idrætsforskere indgår, publicerer med mellemrum resultaterne af sit arbejde. Det gælder også for Nyborg-seminaret. Jørn Hansen (red): Den uforanderlige krop er en rapport, der indeholder indlæggene herfra. Blandt disse påkalder især Henning Eichbergs artikel Mod kroppens historiske materialisme, om b1.a. naturfilosofisk materialisme, sovjetisk og bulgarsk forskning i kroppens elektriske energifelter, sig interesse sammen med 
Lennart Raaholts artikel Krop og tid om kropskultur og mode. Heri argumenteres der for - måske til glæde for de der bliver ruadere og krummere med tiden - at 1990ernes kropsstil vil markere et opgør med 1980ernes strømlinede idealkrop og de fedtsugede lår.

Samme forskernetværk har på tysk udsendt en pjece ved Jørn Hansen og Henning Eichberg: Institut International d' Anthropologie Corporelle (1992), der rummer en beskrivelse af netværkets interessefelter og arbejdsmåde, en status over det hidtidige arbejde samt en oversigt over de deltagende forskere og deres interessefelter.

Man kan kun glæde sig over de fordybelser, der har fundet sted, samt over at man er i færd med at søge nye genstandsområder og problemstillinger. På den anden side savner man fortsat værker og artikler, der til supplement af kodificerede udlægninger, beskæftiger sig med henholdsvis det 20 . århundrede $\mathrm{i}$ længdesnit og ikke mindst efterkrigstidens idræt og kropskultur, som vi stadig ved alt for lidt om. Desuden savner man fortsat lokalhistoriske artikler om idræt og kropskultur, samt større værker der inddrager lokalhistoriske aspekter i analysen af idrætten og kropskulturen i 1800-tallet. Her forestår et stort forskningsarbejde, for så vidt som den lokalhistoriske dimension stadig fylder for lidt $i$ vores fremstillinger. I den forbindelse kan man nok undre sig over, at idrætsforeningerne $i$ betragtning af de mange jubilæer, der finder sted $\mathrm{i}$ disse år, ikke er mere aktive med hensyn til foreningshistorie. Her ville forskningen og de frivillige ledere ellers nok kunne hjælpe hinanden.

Af boghøsten i vore nordiske broderlande må man fra norsk side udover en lille interessant artikel om Merleau-Ponty i Samtiden 1992, nr. 2 af Gunn Engelsrud: Kroppen som subjekt, der i overensstem- melse med titlen, som så mange andre $\mathrm{i}$ disse tider, gør op med tanken om kroppen som blot og bart objekt, især pege på Matti Goksøyrs Dr. scient. afhandling Idrettsliv $i$ borgerskabets by. En historisk unders $\varnothing$ kelse av idrettens utvikling og organisering $i$ Bergen på 1800-tallet (1991). En god og grundig gennemgang af, hvad sportificeringen betød for idrættens udvikling i Bergen.

Svenska idrottshistoriska foreningens årsskrift 1991 holder den samme solide klasse fra de foregående år. Ikke mindst interessant er Anna Gardemann artikel om Torsten Tegner, en af den svenske sportsjournalistiks store mænd, som modsat så mange andre kolleger på ingen måde holdt sig tilbage med hensyn til politisk stillingtagen til de brændende spørgsmål i mellemkrigstiden. Artiklen er god læsning i sig selv, men er desuden udtryk for, at forskning i sportsjournalistikken (endnu) spiller en langt større rolle i Sverige end $i$ Danmark, săledes har Idrottsarvet i Goteborg med Lennart K. Persson som primus motor leveret flere gode bidrag til sportsjournalistikkens ældste historie.

Derudover kan der være grund til at gøre opmærksom på et brag af en artikel, nemlig Jonas Frykmans / rorelse - Kampen om kroppen $i 30^{\prime}$ talets Sverige, i et nystartet etnologi-tidskrift fra Umeå Universitet med titlen Kulturella Perspektiv. I denne artikel hvirvles spørgsmål op, der i høj grad står som et memento til de herskende opfattelser om kropskulturens historie her i landet. Man kan alt efter behov og interesse kalde det en korrektionsmulighed eller et supplement. Under alle omstændigheder făr man her $i$ en kombination (!) af Foucault og folkrorelsestænkning masser at vide om kroppens funktion og betydningsskabende funktion i de 1930' ere, som (jvf. ovenfor) er så underbelyste på dansk. Artiklen udmærker sig ikke mindst ved at påpege, 
hvorledes jorden takket være de livstolkningsmæssige motiver, der daterer sig tilbage til pietismen og til de lægmandsreligiøse bevægelser i første halvdel af 1800 tallet, var gødet for den folkelige udbredelse af den svenske gymnastik på landet $\mathrm{i}$ Sverige som led i en modernisering af bonde-Sverige. Alene i kraft heraf synes artiklen at kunne bruges $i$ en komparativ analyse mellem dansk og svensk civilisationshistorie belyst ud fra en gymnastikhistorie: umiddelbart tror man, at Danmark på dette tidspunkt var tidligere ude med en civilisatorisk anvendelse af den svenske gymnastik. Sandsynligvis åbnede den nok så massive danske anvendelse heraf allerede fra 1880erne, i bl.a højskoleregi, mulighed for en kombination af indrestyret selvdisciplin og kæk italesættelse, således at Niels Bukh i mellemkrigstiden kunne sparke en åben dør ind.

Blandt de mange interessante problemstillinger, som Frykmans artikel berører, er spørgsmålet, hvorvidt kroppen er en repræsentation eller den selv rummer en substantiel viden. Dette spørgsmål, som tilsyneladende står som dét aktuelle spørgsmål i øjeblikket, spiller også en væsentlig rolle $\mathrm{i}$ oversættelsen til dansk af Brian S. Turners vigtige bog fra 1984. På dansk hedder den Kroppen i samfundet. Det er Idrætsforsks fortjeneste at have peget på den som den første i en serie af oversatte værker om kroppens kultursociologiske status, og det er Hans Reitzels forlags fortjenste at have turdet binde an med en oversættelse af et værk, som allerede mange kender fra engelsk. Sammen med det oven for nævnte værk Krop, intuition og bevidsthed har man her et solidt fundament for at komme videre i udforskningen af kropsligheden mellem presentation og re-presentation.

Denne kropslighed er, fremgår det til fulde af årets boghøst, under omkalfatring.
Som Brian S. Turner skriver (s. 41), er de hidtige grænser mellem det naturlige og det sociale under konstant nedbrydning, således at man (jvf. s. 42) har vanskeligt ved at opretholde et skarpt skel mellem henholdsvis kroppen som resultat af sociale processer og kroppen som en organisk helhed hinsides eller forud for al social repræsentation. En sådan dualisme kan ikke opretholdes; i stedet bør man lægge sig efter unders $\varnothing$ gelse af treklangen institutioner, diskurser og egentlige kropslige processer.

I juni afholdt den internationale sammenslutning af idrætshistorikere ISPHES sit første seminar i Turku i Finland. De deltagende oplægholderes bidrag blev til lejligheden udgivet under titlen Sport and culturel minorities med Leena Laine som redaktør. 49 engelsksprogede artikler spændende fra patetisk selvbekendelse, metodiske overvejelser til gedigen historieforskning er indeholdt $\mathrm{i}$ antologien. Antologien kan blandt andet bruges som en målestok for dansk idrætshistorisk forskning. Generelt har vi intet at være flove over. Danske bidragsydere er Else Trangbæk, Jørn Hansen og med et tysk islæt Henning Eichberg.

$E$ af årets $\emptyset$ vrige vigtige udenlandske værker er David Le Bretons Passion du risque, der beskæftiger sig med risikosporten og ultrasporten. Han spørger efter den lyst til at sætte livet på spil, som her er på færde, $i$ en grænseafsøgning, som samfundet af i dag ikke åbner mange muligheder for: er det en kulturel morbiditet eller er det ønsket om heroisme og en samfundsmæssig sjælden kraftanstrengelse med en tilsvarende værdig død, hvis det skulle gå galt? Er det kedsommelighedens yderste konsekvens eller er det ønsket om at opleve, hvorfor fuglene synger, sådan som man kunne læse det i I form for et stykke tid siden, der ligger til grund?

Tysk idrætshistorieforskningnings grand 
old man, Horst Ueberhorst, fyldte 65 år i oktober 1991. I den anledning blev han af kolleger og elever hædret med festskriftet Umbruch und Kontinuitàt im Sport Reflexionen im Umfeld der Sportgeschichte redigeret af Andreas Luh og Edgar Beckers. Det 480 sider store værk indeholder både artikler, som lægger vægt på kildekritisk soliditet, og teoretisk orienterede forsøg med vilje til afprøvning af teser. De tematiske områder omfatter internationale aspekter af idrætshistorie og -organisation, den moderne olympiske bevægelse, den tyske Turnbevægelse, arbejderidrætten samt idrættens socialhistorie $\mathrm{i}$ det 20. århundrede. I et af de mest interessante bidrag peger en anden grand old man, Hans Lenk, i en kommentar til forskellige legeteorier på, at lege- og glædesmomentet endnu ikke er totalt forsvundet for moderne eliteidræt, og at legens unødvendige og overflødige væsen er vanskelig at komme til livs i sporten, men samtidig er han ikke i tvivl om udviklingsgangen... »Mi corazon es tarde«, som Ivan Malinovski skrev for ca. 30 ăr siden.

Yderst aktuel er Die slawische Sokolbewegung. Beitråge zur Geschichte von Sport und Nationalismus in Osteuropa (1991) redigeret af Diethelm Blecking. Her kan man læse om en ældre næsten glemt kropskulturel bevægelse - sokol, en form for folkelig gymnastik- og spejderbevægelse - der i de kommende ăr sikkert vil komme til at spille en rolle for de $\emptyset_{\text {steuro- }}$ pæiske nationers identitetsdannelse. Hvis dette projekt ikke lykkes er der jo mange danskere, der gerne vil låne dem Grundtvig.

Doris Kupper og Lutz Kottmann (red.): Sport und Gesundheit befinder sig i skæringsfeltet mellem humanbiologisk og humanistisk-samfundsvidenskabelig idrætsforskning med hovedvægten lagt på idræts- pædagogiske perspektiver på sundhed og profylakse. Størst relevans i vores sammenhæng har bogens indledningsartikel af Norbert Schulz om historiske stationer inden for den sportspædagogiske tænknings sundhedsmotiver.

Af den $\mathbf{i}$ disse år yderst righoldige britiske forskning inden for idrætshistorie kan man, i aktualitetens navn, pege på John Williams og Stephen Wagg (red.): British Football and Social Change: Getting into Europe. Denne højst vedkommende antologi beskæftiger sig især med samtidshistoriske emner, der nok berører spørgsmålet om hooliganisme, men heldigvis også beskæftiger sig med »almindelige « tilskuere og om det at se på fodbold $\mathrm{i}$ det hele taget. Stephen Waggs artikel Playing the past: the media and the England football team viser, hvorledes mediernes økonomiske interesser nu også er $\mathbf{i}$ færd med at æde sig ind på klubbernes domæner og på selve spillet, sådan som det $\mathrm{i} \emptyset v$ rigt blev påpeget for andre idrætsgrenes vedkommende efter OL i Barcelona. Der er ikke langt til den totale konstruktion af en særlig medieafart af idrætten, der i så fald vil kunne foregå i et hvilken som helst ingenmandsland, et eller andet tilfældigt sted $\mathrm{i}$ verden. Hvilke konsekvenser fodboldindustriens fremmarsch făr for dén specifikke oplevelse af stedsans og lokalt tilhørsforhold, som er så integreret en del af fodboldkulturen, diskuterer John Bale, som flere danske idrætsforskere arbejder sammen med, i sin artikel Playing at home: British football and a sense of place.

Og medens vi er ved fodbold, să lad os slutte af med en virkelig perle, nemlig Henning Eichbergs Crisis and grace: soccer in Denmark $i$ Scandinavian Journal of Medicin, Science and Sports (1992: 2). Denne festlige lille artikel er i udpræget grad udtryk for, at et grundigt kendskab til en spe- 
cifik idrætsgren ikke altid er en fordel, når man skal forholde sig analytisk til den: ens egen grundige indsigt kan spærre for belysningen, medens den udefra kommende undertiden har lettere ved at gennemskue tingene og anskue dem $i$ et helt nyt og spændende perspektiv. Det er nok det sidste, der er på færde, når Henning Eichberg, muntert og humorfyldt, skriver om dansk fodbold. Han er derudover endnu én af de mange tyskere, som venligt glæder sig over, at Danmark blev Europamestre - og markerer dermed den ændring i tyskhed, der lader sig efterspore fra 1890 til 1990: Brygger Carl Jacobsen blev, som John T. Lauridsen (jvf tidligere) skriver, truet med hjemsendelse fra det »tyske« Fan $\varnothing$, fordi han havde væltet nogle tyske flag i de sandborge, som tyske turister havde rejst på stranden. I dag ville begge dele formodentlig være en umulighed. Man omgås som civiliserede mennesker - og dog:

Sidste år blev vi, kort efter at Idrætshistorisk Årbog var udkommet, af en fremtrædende DDGU'er truet med korporlig afstraffelse i form af »et velanbragt spark bagi «. Således placeret med ryggen mod muren er det med nogen ængstelse, vi sender dette års litteraturorientering på gaden. Men på den anden side er DDGU og DDSG\&I nu slået sammen, og så kan man måske håbe på, at der ikke længere i samme udstrækning skydes med skarpt,: skytterne er jo normalt fredelige mennesker, og som Bent Agerskov skriver i Idratsliv 1992, nr. 2 må man tage hatten af for de mange frivillige ledere, der nu uegennyttigt og fredeligt forlader deres poster. Men: truslen var skrevet på Amtsborgmesterpapir.. 